\title{
Withdrawal of European Soil Framework Directive: Reasons and Recommendations
}

\author{
Yijia Chen $^{1}$ \\ ${ }^{1}$ College of Environmental Sciences and Engineering, Peking University, Beijing, China \\ Correspondence: Yijia Chen, College of Environmental Sciences and Engineering, Peking University, Hai Dian \\ District, Beijing, 100871, China. Tel: 136-9141-6665. E-mail: 13691416665@163.com
}

Received: October 20, 2019

Accepted: November 29, 2019 Online Published: December 5, 2019

doi:10.5539/jsd.v13n1p1

URL: https://doi.org/10.5539/jsd.v13n1p1

\begin{abstract}
The European Soil Framework Directive was the first policy approach of soil protection at the European level. It had an objective to protect soils across Europe and maintain the sustainability of soil functions. Notwithstanding the significance of the directive along with both the current state and the trend of the soil in Europe were negative, it had been strongly blocked by five member states of the European Union since it was adopted in 2006, encompassing the UK, Germany, France, the Netherlands, and Austria. The proposal was withdrawn formally on 21 May 2014 by the European Commission without any official statement of reasons. Consequently, this study aimed at the reasons for the withdrawal and the amendments to the directive, which contributed to restoring its role in soil conservation. It ascertained the reasons and proved some recommendations principally via a deductive approach and qualitative research. The results demonstrated that the resistance of the five main blocking countries was the direct factor in the withdrawal. Behind the statements of opponents, financial difficulties and political issues were the possible underlying reasons. Hence, the European Commission could arrange more meetings and change some provisions to eliminate the misunderstanding with its member states. On the other hand, it is sensible for the opponents to be more flexible to deal with the directive, for instance, establishing the benefits from the articles as well as more approaches for solving the problem of financial shortage.
\end{abstract}

Keywords: soil protection, European environmental policy, European soil framework directive, withdrawal

\section{Introduction}

Soil is the zone where plants grow roots, the foundation for terrestrial life, the basis for a great deal of economic production (Environment Agency, 2004). It is the medium for plant growth in agriculture (European Environment Agency (EEA), 2010), comprising transportation and storage. Soil can be considered as a 'Coupler' by virtue of providing an essential connection between the components - pedosphere, hydrosphere, atmosphere, biosphere, lithosphere (ESBN, 2015), and a 'regulator' water supplies with a myriad of micropores which absorb and store the moisture over the period of rain or snow falling upon the land for subsequent utilisation (Plant and Soil Sciences e-Library). In terms of protecting the natural environment, soil has the capability to neutralise and decompose potential contaminants as a natural filter, along with reallocating the excess water to the ground or surface water (Blum, 2005). It also plays a significant role in urban development. For instance, it is a medium of landscaping and engineering, supplying the foundation upon which the buildings, roads, and other infrastructures constructed. (ESBN, 2015).

Healthy soil is considered an essential component to agricultural production, with the capability of supporting the ecosystems on which economic activities and livings rely (European Union, 2006). Land degradation provokes a great deal of direct or indirect costs and consequences. Soil erosion results in the loss of nutrients, which weakens the production and livestock carrying capacity. Additionally, environmental services are caused to lose, and malnutrition as well as poverty become more severe, viz., more financial burdens create on the society, all of which are at considerable cost (Kirui, 2016). Not only does the cost of remediating contaminated sites vary from EUR 30000 per site to EUR 620000 per site, but more than $43 \%$ of total expenditure is generally derived from the public budget in 2008 (Pérez et al., 2018). In light of a study in 2017, European countries loss EUR 1.25 billion in annual agricultural productivity and loss EUR 155 million in the gross domestic product due to soil erosions (Panagos et al., 2017). 
Nevertheless, the ability to perform these aforementioned functions are weakened and even lost without countering (EC, 2002). Over 20 years ago, soil degradation in 28 EU Member States impinged upon an approximate amount of 114 million hectares of land, which is over $35 \%$ of the land area in Europe (Oldeman, 1992). In recent years, there are approximately 2.8 million sites that suffered and are suffering from polluting activities in these countries (Panagos et al., 2017). Moreover, there is a general lack of consciousness as regards soil conservation. As far as environmental issues, the majority of the public are familiar with air and water pollution. The acquaintance of the importance of soil protection is limited, which gives rise to the lack of protection awareness. Not only do merely nine EU member countries hitherto have set the specific act upon soil protection without the assistance from the EU, but there is a dearth of long-term consideration of a wider protection of soil functions.

The European soil framework directive (SFD), which is a significant legislation in terms of solving soil issues with the objectives to protect soils across the EU and ensure sustainable utilisation of soil, filled in the gap indicated above. It was the first specific legislation on soil protection at European level, proposed in 2006. After eight years, however, the aims of the directive were failed and the proposal was formally withdrawn on 21 May 2014 by the European Commission (EC) without any progress. There was merely a document published in the Official Journal of the European Union informing the withdrawal. A blocking minority encompassing five EU member states - the UK, Germany, France, the Netherlands, and Austria, objected to the proposal from the very beginning. Furthermore, Malta was afterwards in sympathy with them. The overriding aim of this paper is to understand the reasons why the European soil framework directive failed and to offer some recommendations for how it can be taken forward.

\section{Analysis of the SFD}

\subsection{Background}

Although there were more than two hundred of environmental directives and regulations, there was no specific soil legislation or legal instrument directly concerned with soil protection at the EU level (Kraemer, 2004) until 2006. In September 2006, the EC adopted a Soil Thematic Strategy to fill the gap in European environmental legislation and to provide a more holistic approach to soil protection in the EU (EC, 2016), which comprises a proposal for a framework Directive on the protection of soil, as the optimum medium of ensuring a comprehensive approach to soil protection (EC, 2006b). However, some member states, including the UK, Germany, France, the Netherlands, and Austria, strongly disagreed with the directive. Due to the constant block by these countries, the directive was finally withdrawn in 2014 (Official Journal of the EU: C153, 2014).

\subsection{Merits and Breakthroughs}

At the European Community level - Actions at EU level are the essential additions to the member states making decisions (EC, 2006b) with three main factors and benefits. First, European soil protection policies have valuable influence on global dimension. The EU can play a leading role internationally, facilitating the transfer of expertise and technical assistance whilst at the same time ensuring the competitiveness of their economies, whereby establishing an appropriate and coherent framework which will translate into better acquaintance and management of soil (Glæsner et al., 2014). Second, uniform actions can prevent internal conflicts. A common soil framework promotes the accordance of soil protection obligations of land administrators, thereby increasing the stability of the internal market and reducing the distortion of competition between member states (Glæsner et al., 2014). Policies at EU level also contribute to European integration. Article six of the European Community Treaty provides that it is required to integrate the field of environmental protection in all EU sectoral policies to facilitate sustainable development (European Union, 2002), along with the enhancements of economic, social, territorial cohesion and solidarity among EU member states.

Consistency with the other policies and objectives of the Union - This proposal, which aims at the protection of the capacity of soil related to agriculture, environment, nature protection, and urban applications, corresponding to the objectives of the Article 174 of the EC Treaty (European Commission, 2006). Additionally, the proposal provides that it is important to ameliorate the state of soil at the source and the polluters ought to discharge a relevant duty, according to the precautionary principle, polluter pays principle, along with the Prevention Principles (European Commission, 2006).

Highlight the importance of the community - The directive incorporates considerable opinions from a wide range comprising 287 organisations together with 1,583 people, involving national, regional and local administrations, environmental organisations, the EEA, the unions, science and research institutes, landowner organisations and farmer organisations (EC, 2006c). There are two comprehensive reports completed by these working groups. One is regarding the state of soils in Europe as well as the relevant suggestions in 2004, with the intention of 
advancing a soil legislation at EU level (EC, 2006c). The other one is on the statistical analysis of all questions in the Impact Assessment (EC, 2006e), encompassing the process that how the feedback has been taken into account and nationality distribution of the interview targets.

\subsection{Limitations}

- Unclear and vague - The SFD has several requirements. It proposes that during the planning process with the intention of maintaining the soil functions as many as possible by means of taking a set of appropriate actions (EC, 2006b). Nevertheless, it does not provide specific guidelines and implementation measures to meet the requirements. With regard to the specific measures, it is likewise ambiguous, which gives rise to the different understanding of the articles. Ambiguities not only results in the uncertainty to the national authorities but in a possibility of the complete resistance (Wallace, 2005).

- Stick on the uniform and fixed approach - It is unreasonable to force all member states to adopt the same method, given that there are many differences among European countries especially related to the extent of soil degradation, although the directive realises that 'Wide differences between national soil protection regimes, in particular as regards soil contamination'. The two opposite demonstrations seem that the directive is considered self-contradictory to a certain extent.

- Hamper the existing national soil protection legislation - There might be a considerable discrepancy between SFD and existing policies of Member States. Article 12 (EC, 2006c) claims that Member States should ensure there is a soil status report available to the competent authority and to the other party in the transaction, in order to sell a polluted or potentially polluted site. This proposed Article may interfere with the national procedures for land transfer. For instance, buyers in Great Britain are free to further investigate the risk involved for them with their options, and the value of this investment will be disproportionately decreased by virtue of the time along with the cost involved in completing the impact assessment report (Scottish Executive, 2007).

- Put economic and ethical pressure on authorities - The proposal declaims that other countries are in considerable need of expertise and technical assistance (EC, 2006c), and Article 15 (EC, 2006c) requests the EU member states to take measures to transfer the acquaintance and experience as regards the sustainability of the soil functions. These declarations may prompt reluctance to comparatively more developed countries. Moreover, Member States were urged to establish specific funding mechanisms, with the responsibility for the orphan contaminated sites which cannot be held liable for the pollution under national or Community legislation or cannot be made to bear the costs of remediation (EC, 2006c). This provision is stressful to local governments, since the environmental liability could be difficult to exercise, in particular in the contaminated zones with a long history where it is difficult to state the personal responsibility for the pollution. As a result, the majority of the payment will be charged to the authorities. This result undoubtfully put considerable economic pressure on authorities.

- Mandatory restrictions - One of the provisions in the proposal is: Appropriate measures are needed to limit soil sealing, for instance by rehabilitating brownfield sites, thereby reducing the depletion of greenfield sites; Where sealing does occur, the member states should provide for construction and drainage techniques that would allow as many soil functions as possible to be preserved (EC, 2006c). This provision demonstrates that the requirements of the EU are mandatory, which violates the original intention of European Directives and the SFD. It should not be ignored that a European directive is a form of legislation which merely discharges a duty regarding 'directed' at the member states, with leaving the choices of approaches and methods to the national authorities (Wallace, 2005).

\section{Reasons for the Withdrawal}

\subsection{Direct Reasons}

The proposal of SFD took every step with difficulty. It met with considerable opposition from a minority of countries in the Council of Ministers at the outset (Hasegawa, 2016). These 'blocking countries' are listed above. Negotiations between member states had been 'very, very difficult', according to one EU official once close to the discussions (EURACTIV, 2007). France, Finland, and Sweden merely expressed skepticism about the new law, but opposition from these member states was less rigid. But France ultimately sided with the UK and Germany, who also received backing from Austria and The Netherlands. Notwithstanding the support of 22 other EU member states and "various attempts" by the Portuguese EU Presidency to reach a compromise, a qualified majority could not be reached (Hasegawa, 2016).

The direct reason for the withdrawal is the constant disapproval. What the limit is that there is no official 
document exhaustively recording the event, and just a few research papers mentioned it. As a result, there are merely seven statements available online. All the statements and the articles possibly corresponding to the statements are listed in Table 1 below:

Table 1. Statements from the opponents

\begin{tabular}{|c|c|c|}
\hline $\begin{array}{l}\text { Blocking } \\
\text { countries }\end{array}$ & Statements & Corresponding articles \\
\hline \multirow{4}{*}{$\begin{array}{l}\text { The United } \\
\text { Kingdom }\end{array}$} & $\begin{array}{l}\text { The UK is concerned about } \\
\text { additional policy obligations as } \\
\text { well as a possible restriction on } \\
\text { housing developments }\end{array}$ & $\begin{array}{l}\text { Article 12: } \\
\text { Member States shall ensure that the owner of that site or the } \\
\text { prospective buyer makes a soil status report available to the } \\
\text { competent authority referred to in Article } 11 \text { and to the other party in } \\
\text { the transaction. }\end{array}$ \\
\hline & SFD would lead to & \\
\hline & $\begin{array}{l}\text { 'disproportionate' cost with a } \\
\text { negligible environmental benefit. }\end{array}$ & Overall \\
\hline & $\begin{array}{l}\text { The UK has particular } \\
\text { geographical circumstances with } \\
\text { a low risk of transboundary } \\
\text { effects }\end{array}$ & Overall \\
\hline $\begin{array}{l}\text { German, } \\
\text { Austria }\end{array}$ & $\begin{array}{l}\text { SFD breaches the 'subsidiarity } \\
\text { principle' }\end{array}$ & Overall \\
\hline \multirow{3}{*}{$\begin{array}{l}\text { Austria, France, } \\
\text { Germany, } \\
\text { the } \\
\text { Netherlands, } \\
\text { the United } \\
\text { Kingdom, } \\
\text { Malta }\end{array}$} & $\begin{array}{l}\text { It would be too expensive to } \\
\text { implement SFD (like cleaning up } \\
\text { contaminated sites) }\end{array}$ & $\begin{array}{l}\text { Article } 1 \text { (or Overall): } \\
\text { This Directive establishes a framework for the protection of soil and } \\
\text { the preservation of the capacity of soil to perform any of the } \\
\text { following environmental, economic, social and cultural functions. To } \\
\text { that end, it lays down measures for the prevention of soil degradation } \\
\text { processes, both occurring naturally and caused by a wide range of } \\
\text { human activities, which undermine the capacity of a soil to perform } \\
\text { those functions. }\end{array}$ \\
\hline & $\begin{array}{l}\text { SFD would place undue extra } \\
\text { trouble on countries which has } \\
\text { already implemented specific soil } \\
\text { policies or legislation at the } \\
\text { national level. }\end{array}$ & Overall \\
\hline & $\begin{array}{l}\text { SFD unfairly places the burden of } \\
\text { liability on land-users rather than } \\
\text { those responsible for soil damage. }\end{array}$ & $\begin{array}{l}\text { Article 4: } \\
\text { Member States shall ensure that any land user whose actions affect } \\
\text { the soil in a way that can reasonably be expected to hamper } \\
\text { significantly the soil functions referred to in Article 1(1) is obliged to } \\
\text { take precautions to prevent or minimise such adverse effects. }\end{array}$ \\
\hline
\end{tabular}

\subsection{Underlying Reasons}

\subsubsection{Great Expense and Business Interruption}

The Soil Framework directive may cause great expense. Not only does it cost exceedingly, but it can be considered a stumbling block in earnings. The Soil Framework Directive may substantially impinge upon the 
approach of identifying the contaminated sites. It requires the landowners and administrators to take appropriate measures to assess the soil with contamination level, which is obliged to be listed in the National Registry (EC, 2006c). This requirement will put an extra financial burden on both the landowners and National Registry, which signifies that it is necessary and mandatory to recognise the elaborate system in place (EC, 2006d).

Moreover, there is a thorough budget in the official document SEC(2006)620 (EC, 2006e). Take the data on the cost of dealing with contaminated sites as an example. The prior survey serves as the very beginning of the inventory process. This stage primarily encompasses a desk study on existing information, based on which potentially contaminated sites are identified. In agreement with the Soil Framework Directive, this procedure will be required to be carried out within 5 years after its transposition. At the first stage, the total costs for the EU member states could be monetised according to the existing available information from 13 Member States which have already carried out or are in the moment carrying out such a prior survey, as well as the Dutch inventory 'Landsdekkend Beeld' (EC, 2006e). The estimated additional costs in total for the prior survey are EUR 51 million to EUR 255 million per year for all the member states for the first five years after their transpositions of the SFD. Table 2 (EC, 2006e) shows the results.

Table 2 Estimated additional costs to establish a preliminary survey (first five years)

\begin{tabular}{llc}
\hline \multicolumn{1}{c}{ Types of cost } & \multicolumn{1}{c}{ Cost amount (million) } \\
\hline$\quad$ Costs of preliminary survey & $>€ 680$ \\
$>\quad$ Expenses already incurred and identification \\
already carried out by 13 Member States (25\% of \\
the total)
\end{tabular}

In terms of the concern from the UK about additional policy obligations as well as a possible restriction on housing developments, implementing the directive might be a stumbling block in the mechanism of making money. For instance, as the price of the land might have changed due to present contamination, which has to be made public it might affect the house owners as the price of their house could rapidly fall due to such contamination (Scottish Executive, 2007).

\subsubsection{Economic Frustration}

Europe abruptly ran into a severe financial crisis in 2008, followed in many countries by a second recession in the period 2010-2012 (Clench, 2017), which caused radical changes to the economic strategies of many states, with concomitant effects upon a range of policy sectors (Burns, 2016). The negative impact of the crisis on the environment is obvious. First, participants are worried about the situation that the momentum will be diverted amid the economic crisis in the worldwide environmental movement. Since it is reasonable for the government policies to prioritize employment fixes and fast economic development. Moreover, there is another apprehension that approved policies are possible to be pending for a long period by virtue of the cost. In terms of the enforcement, notwithstanding there is no assessment of the influence of the stimulus investment of the regimes on the predominant industries, the participants predict that it is possible to arouse a couple of issues, encompassing weak regulatory oversight, heavy energy consumption, along with heavy pollution. In addition, the weakening of the market together with the strengthening of government intervention is likewise a considerable potential trouble. It may result in a set of further administrative issues with individual interests exceeding national ones, which comprises the local enterprises that are deleterious to the environment, as well as the purposes of the citizens and national environmental goals (Zhang, 2009).

\subsubsection{Political Conflicts}

- Not comply with the Subsidiarity Principle - Drawing all objects and approaches at a European level in legislative proposals dealing with the various soil threats is not considered compatible with the subsidiarity Principle (EC, 2006d). SFD was considered an interference in domestic policy. The British and German governments asserted that the EU had no business to regulate soil because it is not a cross-border issue (Stankovics, 2018). It is suggested that notwithstanding a majority of the European countries have no 
legislative text or framework, it is significant to pay attention to the minority which has enacted their own soil protection policy (Scottish Executive, 2007).

- Difficult to unify all the member states - Since countries vary in their regulatory styles and philosophies (Richardson 1982; Vogel 1986), the governments should concentrate on not only the level of standards, the degree of scientific uncertainty acceptable prior to imposing European approaches, the amount of administrative or regional flexibility desirable, but the type of policy instruments which are utilised to be employed (Wallace, 2005). All of these factors are not considered in the proposal of the SFD.

- A change of sovereign brings a change of decision - The governments of the EU member states vary their positions over time if either the economic and environmental conditions change or a new government with different policy priorities come to power. For instance, the United States Department of Energy did not modify its opinion which objected to a European proposal at that time, until the French presidency (Wallace, 2005).

\section{Discussion}

One reason for the withdrawal is that the opponents complained about the great expense. Indeed, as shown in the official documents SEC(2006)620 (EC, 2006e), there is a list of budgets in detailed. Although it does not cost little, the opponents ignored that the benefit will finally offset the capital and exceed it. For instance, it will cost $€ 50$ - 290 million per year for the member states for the first 5 years, while the budget will be up to $€ 240$ million per year in years 6-25, with only $€ 2$ million per year in total afterwards (EC, 2006e). Apart from the decline in the cost, there is a great deal of priceless benefit, encompassing: Address soil protection and combat soil threats systematically, effectively and efficiently; adopt more targeted and efficient measures; plan in the mid and long term their strategies to combat soil degradation in their territory; stimulate sustainable use of soil, and take a preventive approach thus saving costs so far borne by society to a far greater extent than the additional costs of the SFD. As a result, it is thoughtless to merely concentrate on the cost.

The opponents, in particular the UK, announced that the SFD will restrict the source of income. It is said that there is a negative effect on housing development since the directive requires member states to ensure that the owner of that site or the prospective buyer makes a soil status report available to the competent authority referred to in Article 11 and to the other party in the transaction (EC, 2006c). However, they are merely concentrated on the turnover of trading the land without a judgment that if the land was contaminated, alternatively how much the contaminated land would be harmful to the health of residents who live in pollutants. The people who are living in a contaminated environment not only will catch a variety of illness, as well as their offspring will have many strange and serious genetic diseases. Provided that the majority of the population are unhealthy, it is of no consequence to accumulate a great deal of wealth. Given that this result is considered a disaster for a country, even for all mankind, the Article 11 in the SFD is necessary and urgent.

In terms of the politic factors, it is much more complicated to address a conclusion. Since political science contains a wide range of theories, encompassing politics, psychology, the Game Theory. As the analysis in the Section 3.2.3, a decision is influenced by the current authority. New governors will always adopt the styles which have accompanied them for many years. Moreover, there will be a set of replacement for old habits, for instance, slogans, thoughts, or principles. As a result, it might be unfortunate under the governance which held no interests in the directive. On the other hand, given that the proposal for the SFD was pending in the period of eight years. This circumstance might be regarded as an escape. It is complicating to solve the issues of soil, with a long-term plan, implementation, and monitor. There might be a willing of the current authority to hand over such an exacting assignment to the next leadership.

\section{Recommendations}

According to the discussion above, both the blocking minority and the EU have the responsibilities for the withdrawal of the proposal for SFD. It is necessary for them to conduct more negotiations, along with the concessions between each other to a certain extent. This chapter provides a couple of suggestions separately referring to the EU and the opponents.

It is more effective for the EU to replace the penalty with rewards. Punishment is easy to cause rebellious psychology, which do not contribute to the implementation of SFD. Therefore, the EU can discard the penalty provision and try to adopt a reward system. For instance, those countries which complete missions can have the policy of tax reductions and exemptions. Additionally, the EU should reconsider the Subsidiarity Principle. Given that the opponents are unsatisfied with a couple of mandatory articles, it is reasonable for the directive to modify some articles which leave enough space for member states to identify the most appropriate approaches. 
Moreover, the EU regulations on soil should be designed to intervene only where action is required (European Union, 2013).

There are more suggestions to the member states. It is probably of more reasonableness to consider the expenditure from another perspective, change the attitude towards those in poverty, become more objective and considerate to the SFD.

- It would not cost much - The opponents argue that it would be expensive to implement the directive. It should be noted that the high costs of cleaning up contaminated sites, in reality, is an argument in favour of this directive, since only if there is an obligation to de-pollute can it prevent the deleterious influence and avoid the contamination in the future. Provided that soil degradation does not cease currently by means of a harmonising EU directive, the subsequent cost to the economy could run into billions (EEB, 2011). In the longer term, the benefits for the member states will outweigh the costs. European countries ought to be confident and believe that costs will decrease, as some threats will totally disappear in some areas. Benefits will increase with time, as soil fertility and soil functions are restored. Benefits will also accrue gradually as measures taken begin to have a positive impact across a range of areas where the current costs of degradation are felt (EC, 2006d).

- Not being resistant to those in poverty but seeking cooperation - The rich, northern environmental proponents may not be willing to give assistance to the poorer, southern states, which is the conflicts of interest that emerged between leaders and laggards. The leaders refer to the countries like Germany, the Netherlands, Sweden, and Denmark, i.e. the richer, northern states - whereas the laggards are the poorer, southern states like Greece, Spain, Portugal, and the new member states. It is accessible for the rich to refuse to do involuntary charity, but they can treat it as a win-win cooperation with the benefits and investment priorities, including local cheap labor, strengthening international friendly relations, and stabilising the safety in the world. The investment in Africa by China is a corresponding case. While Europeans and Americans consider Africa a troubling source of instability, migration, and terrorism, it is affluent with myriad precious minerals - oil, copper, cobalt and iron ore. It has markets for Chinese manufacturers and construction companies. Additionally, perhaps, it is a promising vehicle for Chinese geopolitical influence.

- Eliminate misunderstanding - The opponents argue that an exceedingly rigid implementation of the SFD may give rise to the infringement of national standards (EEB, 2011). In contrast, the directive will not intervene in the existing domestic legislation. It declaims that the uniform provisions are merely the minimum standard aimed at the member states, viz., provided that there is a higher standard legislation in a domestic law, the citizens in that country should adhere to their own legislation. Therefore, the opponents might misunderstand the directive.

- Become more thoughtful. It is pointed out that the SFD is not compatible with the Subsidiarity Principle. The opponents claim that the issue of soils can be best addressed at national and regional levels, given that the soil is a matter of national interest by its nature. Nevertheless, they thoroughly ignore the transboundary impacts of soil deterioration.

\section{Conclusion}

The importance of soil protection is to maintain the soil functions which signifies the sustainability of the natural environment and human society. Given that ameliorating the state of the soil in Europe is one of the ultimate objectives of the SFD, it is likewise of enormous importance. Although the directive has several merits and even breakthroughs, there is considerable room for improvement.

While there was no official statement to explain the reasons for withdrawing the SFD, it can be analysed that there is a couple of direct and indirect factors giving rise to the withdrawal. A blocking minority which is organised in the five EU member states is the direct factor. The reason why they refuted is that a high additional cost along with a reduction in business are raised with the SFD. Moreover, they deemed that the directive did not comply with the Subsidiarity Principle, and it is difficult to unify all EU countries. The position of the opponents might be related to the sovereign of that period, since governments alter their positions over time, if either the economic and environmental conditions change or a new government with different policy priorities comes to power.

All things considered, it seems reasonable to assume that notwithstanding the failure of the SFD induced by integrated reasons, it is possible to take it forward via a couple of amendments of the directive and more negotiations between the EU and its member states. Not all the complaints from the blocking minority are 
corresponding to the fact, since there are several misunderstandings and false judgment about the directive. It can be summarised that the withdrawal is related to both the EU and the opponents.

Inasmuch as there are seldom published copy of documents and literature, this paper mainly depends on the author's understanding and analysis, with endeavouring to search for other papers as many as possible to support the opinions. It also reflects that the acquaintance of the withdrawal of the directive and soil conservation remains extremely poor. Hence, with regard to the future study, it is more sensible to directly ask the EU officials for relevant copies of documents, especially for the record of every meeting, for instance, the videotape. Alternatively, interviewing the officials via flying to Luxembourg is an auxiliary, more reasonable, and an interesting approach.

\section{Acknowledgement}

I would like to thank Dr. Martin K Head who was my tutor during the postgraduate study for his encouragement and assistance, which is helpful to the constant modification of the structure and contents of this paper.

\section{References}

Burns, C., \& Tobin, P. (2016). The Impact of the Economic Crisis on European Union Environmental Policy. JCMS, 54(6), 1485-1494. Retrieved from https://onlinelibrary.wiley.com/doi/pdf/10.1111/jcms. 12396

Clench, J., \& Holte, A. (2017). The financial crisis in Europe: Impact on satisfaction with life. Scandinavian Journal of Public Health, 45(Suppl 18), 30-40. Retrieved from http://journals.sagepub.com/doi/pdf/10.1177/1403494817718692

EEA. (2010). The State of Soil in Europe - A contribution of the JRC to the European Environment Agency's Environment State and Outlook Report. Retrieved from http://publications.jrc.ec.europa.eu/repository/bitstream/JRC68418/lbna25186enn.pdf

EEB. (2011). Soil: Worth Standing your ground for. Arguments for the Soil Framework Directive. Retrieved from file://C:/Users/yy/AppData/Local/Packages/Microsoft.MicrosoftEdge_8wekyb3d8bbwe/TempState/Downl oads/Briefing-on-the-need-for-a-Soil-Framework-Directive\%20(1).pdf

Environment Agency. (2004). The state of soils in England and Wales. Retrieved from http://www.adlib.ac.uk/resources/000/030/045/stateofsoils_775492.pdf

ESBN. (2015). Soil atlas of Europe. Office for Official Publications of the European Communities, L-2995 Luxembourg, 10-13, 108-117.

EURACTIV. (2007). EU soil protection law blocked by UK, France and Germany. Retrieved from https://www.euractiv.com/section/climate-environment/news/eu-soil-protection-law-blocked-by-uk-france-a nd-germany $/ 823367 /$

European Commission. (2006). Directive of the European Parliament and of the Council establishing a framework for the protection of soil and amending Directive 2004/35/EC COM(2006)232 final. Brussels, Belgium, European Union. Retrieved https://eur-lex.europa.eu/LexUriServ/LexUriServ.do?uri=COM:2006:0232:FIN:EN:PDF

European Union. (2002). Consolidated versions of the treaty on European union and of the treaty establishing the European community. Official Journal of the European Communities, 2002/C 325/01. Retrieved from https://eur-lex.europa.eu/legal-content/EN/TXT/PDF/?uri=CELEX:12002E/TXT\&from=EN

European Union. (2006). Questions and answers on the Thematic Strategy on soil protection. Brussels, MEMO/06/341.

European Union. (2013). Opinion of the Committee of the Regions on 'Implementation of the Soil Thematic Strategy'. Official Journal of the European Union, C17/37-44. Retrieved from https://eur-lex.europa.eu/legal-content/EN/TXT/PDF/?uri=CELEX:52012AR1121\&from=EN

Glæsner, N. et al. (2014). Do Current European Policies Prevent Soil Threats and Support Soil Functions? Sustainability, 6(12), 9538-9563; doi:10.3390/su6129538. Retrieved from http://www.mdpi.com/2071-1050/6/12/9538/htm

Hasegawa, H. et al. (2016). Environmental remediation technologies for metal-contaminated soils. Springer Japan. Retrieved from https://eur-lex.europa.eu/legal-content/EN/TXT/PDF/?uri=CELEX:52006DC0231\&from=EN

Kraemer, R. et al. (2004). EU Soil Protection Policy: Current Status and the Way Forward. Ecologic, Berlin. 
Retrieved from https://www.ecologic.eu/sites/files/project/2013/1965_background_paper.pdf

Nexis, L. (2014). Why was the Soil Framework Directive withdrawn? Retrieved from https://blogs.lexisnexis.co.uk/purposebuilt/why-was-the-soil-framework-directive-withdrawn/

Oldeman, L. R. et al. (1992). World map of the status of human-induced soil degradation, an Explanatory Note. Winand Staring Centre, Wageningen, the Netherlands, Global Assessment of Soil Degradation (GLASOD) project. Retrieved from http://www.the-eis.com/data/literature/World $\% 20$ map $\% 20$ of $\% 20$ the $\% 20$ status $\% 20$ of $\% 20$ human-induced $\%$ 20soil\%20degradation_1991.pdf

Panagos, P. et al. (2017). Cost of agricultural productivity loss due to soil erosion in the European Union: From direct cost evaluation approaches to the use of macroeconomic models. Land Degrad Dev., 471-484. https://doi.org/10.1002/ldr.2879

Pérez, A. P., \& Eugenio, N. R. (2018). Status of local soil contamination in Europe. European Commission. Report number: EUR 29124 EN.

Plant and Soil Sciences e-Library. (n.d.). Soil Genesis and Development, Lesson 6 - Global Soil Resources and Distribution. $\quad$ Retrieved July 16, 2018, from http://passel.unl.edu/pages/informationmodule.php?idinformationmodule $=1130447033 \&$ topicorder $=3 \& \max$ to $=7$

Scottish Executive. (2007). Consultation on the proposed EU Soil Framework Directive and initial Regulatory Impact Assessment. Edinburgh: Scottish Executive Environmental Quality Directorate Soil Policy Coordination Team. Retrieved from https://www.gov.scot/Publications/2007/07/30113343/0

Stankovics, P. (2018). Identifying Gaps between the Legislative Tools of Soil Protection in the EU Member States for a Common European Soil Protection Legislation. Retrieved from https://www.mdpi.com/2071-1050/10/8/2886/pdf

Wallace, H. et al. (2005). Policy-Making in the European Union (5th ed.). Oxford, Oxford University Press.

Zhang, S. (2009). The Environmental Impact of the Financial Crisis: Challenges and Opportunities. Retrieved from

https://carnegieendowment.org/2009/04/11/environmental-impact-of-financial-crisis-challenges-and-opport unities-event-1328

\section{Copyrights}

Copyright for this article is retained by the author(s), with first publication rights granted to the journal.

This is an open-access article distributed under the terms and conditions of the Creative Commons Attribution license (http://creativecommons.org/licenses/by/4.0/). 